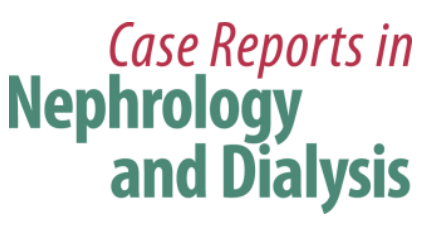

Case Rep Nephrol Dial 2016;6:61-69

DOI: $10.1159 / 000445679$

Publisnea oninne: ApriI 14, 2016

\title{
Diverse Renal Phenotypes Observed in a Single Family with a Genetic Mutation in Paired Box Protein 2
}

\author{
Yoichi Iwafuchi ${ }^{a}$ Tetsuo Morioka ${ }^{b}$ Takashi Morita $^{c}$ Toshio Yanagihara $^{e}$ \\ Yuko Oyama $^{a} \quad$ Naoya Morisada $^{f}$ Kazumoto Iijima $^{f} \quad$ Ichiei Narita $^{d}$ \\ ${ }^{a}$ Department of Internal Medicine, Koseiren Sanjo General Hospital, Sanjo, ${ }^{b}$ Department of \\ Internal Medicine, Kidney Center, Shinrakuen Hospital, 'Department of Pathology, \\ Shinrakuen Hospital, and ${ }^{\mathrm{d} D i v i s i o n}$ of Clinical Nephrology and Rheumatology, Niigata \\ University Graduate School of Medical and Dental Sciences, Niigata, ${ }^{e}$ Department of \\ Pediatrics, Yoshida Hospital, Tsubame, and ' Department of Pediatrics, Kobe University \\ Graduate School of Medicine, Kobe, Japan
}

\section{Key Words}

Paired box protein 2 mutation - Renal coloboma syndrome $\cdot$ Focal segmental glomerulosclerosis - Congenital anomalies of the kidney and urinary tract · Autophagic dysfunction · Funduscopic examination

\begin{abstract}
A common renal phenotype of paired box protein 2 (PAX2) mutations is renal coloboma syndrome. We report a single family with diverse renal phenotypes associated with PAX2 mutation. The proband presented steroid-resistant focal segmental glomerulosclerosis with optic coloboma, whereas his two sons showed severe renal hypoplasia with end-stage renal disease, with or without optic coloboma. In all three cases, a heterozygous PAX2 genetic mutation was identified (exon 2; NM_003987.3:c.76dupG, p.Val26Glyfs*28). Based on histopathological findings of the proband, we hypothesized that autophagic dysfunction was associated with the pathophysiology of the focal segmental glomerulosclerosis with PAX2 mutation. Detailed funduscopic examination - including the optic disc - might be useful for the diagnosis of renal anomalies associated with PAX2 mutation.




\section{Case Reports in \\ Nephrology \\ and Dialysis}

Case Rep Nephrol Dial 2016;6:61-69

DOI: $10.1159 / 000445679$

(C) 2016 The Author(s). Published by S. Karger AG, Basel www.karger.com/cnd

Iwafuchi et al.: Diverse Renal Phenotypes Observed in a Single Family with a Genetic Mutation in Paired Box Protein 2

\section{Introduction}

The paired box protein 2 (PAX2) gene encodes a transcription factor essential for differentiation of the epithelial components of the fetal kidney and ureter. Two intact copies of the gene are required for normal renal development [1]. The most common findings associated with PAX2 mutations are abnormal renal structure or function (92\%), ophthalmological anomalies (77\%), and hearing loss (7\%) [2]. Mutations in PAX2 are a common cause of renal coloboma syndrome (RCS) and are usually present early in life. Recently, using in silico analysis and functional data, Barua et al. [3] reported that PAX2 missense variants may lead to an expanded phenotypic spectrum: not only to congenital anomalies of the kidney and urinary tract (CAKUT), but also to focal segmental glomerulosclerosis (FSGS), through haploinsufficiency and/or dominant negative effects. However, the characteristic clinicopathological features of FSGS associated with PAX2 mutations are still unknown.

In this report, we describe a single family with diverse renal phenotypes, such as FSGS and CAKUT, associated with PAX2 mutation.

\section{Case Reports}

Case 1 (the proband), a 27-year-old man, was admitted because of a 7-year history of proteinuria. He had been born at full term and his growth and development had been normal. There was no family history of renal disease. Physical findings were as follows: height $174.0 \mathrm{~cm}$, weight $71.5 \mathrm{~kg}$, body mass index 23.6, and blood pressure 120/80 $\mathrm{mm} \mathrm{Hg}$. He did not suffer from deafness. The rest of the physical examination was unremarkable. Urine dipstick analysis was negative for occult blood and 2+ for protein. Urinary protein was 1.6$3.0 \mathrm{~g} /$ day. The urinary sediment contained $<1$ erythrocyte and 3-5 leukocytes per highpower field. Hematocrit was 43.0\%, hemoglobin concentration $15.2 \mathrm{~g} / \mathrm{dl}$, platelet count $277,000 / \mu \mathrm{l}$, and leukocyte count $6,200 / \mu \mathrm{l}$. The serum urea nitrogen level was $15.4 \mathrm{mg} / \mathrm{dl}$, creatinine $1.0 \mathrm{mg} / \mathrm{dl}$, uric acid $7.9 \mathrm{mg} / \mathrm{dl}$, cholesterol $222 \mathrm{mg} / \mathrm{dl}$, total protein $7.2 \mathrm{~g} / \mathrm{dl}$, and albumin, $4.9 \mathrm{~g} / \mathrm{dl}$. IgG level was $1,070 \mathrm{mg} / \mathrm{dl}$, IgA $139 \mathrm{mg} / \mathrm{dl}$, and IgM $84 \mathrm{mg} / \mathrm{dl}$. Total complement level was $35 \mathrm{IU} / \mathrm{l}, \mathrm{C} 372 \mathrm{mg} / \mathrm{dl}$, C4 $29.5 \mathrm{mg} / \mathrm{dl}$, and C1Q $12.8 \mathrm{mg} / \mathrm{dl}$. Antinuclear antibody was negative. The remaining autoimmune serological findings were within the normal range, and serum viral hepatitis markers were negative. Abdominal computed tomography and ultrasound showed slightly small kidneys with bilateral cysts. Funduscopic examination by portable ophthalmoscope was normal. On the eighth hospital day, a right renal biopsy was performed. Under light microscopy, ten glomeruli and a localized area of tubular atrophy were found (fig. 1a). One glomerulus was obsolescent and in another there was segmental sclerosis with hyaline deposits near the vascular pole (fig. 1b). Other glomeruli were slightly enlarged and had essentially minor changes, but in several segments a questionable increased mesangium was observed (fig. 1c). By immunofluorescence, no significant deposits of immunoglobulins or complement components were found, except for weak granular mesangial and paramesangial IgM deposits. From the clinical and histological findings, idiopathic FSGS was considered as a tentative diagnosis. Initially he was treated with platelet aggregation inhibitor and low-protein diets in our outpatient clinic, but the treatment was interrupted 3 months after admission. At the age of 31 years, he visited our hospital again to be checked for proteinuria. His urinary protein was $51 \mathrm{mg} / \mathrm{dl}$ and $0.8 \mathrm{~g} / \mathrm{day}$, his serum urea nitrogen level was $17.3 \mathrm{mg} / \mathrm{dl}$, and creatinine was $1.1 \mathrm{mg} / \mathrm{dl}$. To clarify the indication of prednisolone, a second renal biopsy was performed. Under light microscopy, only five glomeruli were found, but significant histological changes were not observed expect for 


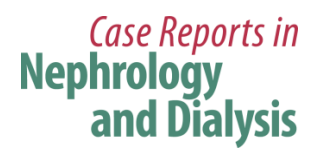

Case Rep Nephrol Dial 2016;6:61-69

DOI: 10.1159/000445679

(c) 2016 The Author(s). Published by S. Karger AG, Basel www.karger.com/cnd

Iwafuchi et al.: Diverse Renal Phenotypes Observed in a Single Family with a Genetic Mutation in Paired Box Protein 2

focal tubular atrophy with mild interstitial cell infiltration. The patient was treated with $40 \mathrm{mg} /$ day of prednisolone with gradual tapering for 18 months in our outpatient clinic, but the proteinuria was steroid-resistant and remained at about 1.0-1.5 g/day. His renal function gradually worsened. At the age of 52 years, his urinary protein was $64 \mathrm{mg} / \mathrm{dl}$ and his serum creatinine level $1.73 \mathrm{mg} / \mathrm{dl}$.

Case 2 (the proband's eldest son) was born by Cesarean section at 39 weeks of gestation when his father, case 1, was 27 years old, with a normal birth weight of 2,880 g but a right pneumothorax and hypoxic ischemic encephalopathy. When he was 2 years old, proteinuria and renal dysfunction were noted. He was suspected to have familial juvenile nephronophthisis. His renal function gradually worsened, and he started continuous ambulatory peritoneal dialysis at the age of 5 years. He received a kidney transplant from a brain-dead donor at the age of 8 years. He is now 26 years old and free from dialysis; his serum creatinine level is $0.80 \mathrm{mg} / \mathrm{dl}$.

Case 3 (the proband's second son) was born by Cesarean section at 41 weeks of gestation when the proband was 28 years old, with a normal birth weight of 3,034 g. From the time of birth, he had proteinuria and renal dysfunction, and ultrasound showed bilateral hypoplastic kidneys. His renal function gradually worsened, and he started continuous ambulatory peritoneal dialysis at the age of 7 years. He received a kidney transplant from his mother at the age of 8 years. After renal transplantation, his renal function gradually worsened because of chronic rejection. He was referred to our hospital to start regular hemodialysis at the age of 23 years. He is now 25 years old and is receiving regular hemodialysis therapy at our hospital.

We initially considered that case 1 was a sporadic case of idiopathic FSGS. However, upon his second son's visit to our hospital, we assumed the existence of a hereditary cause associated with renal hypodysplasia. After obtaining informed consent, we collected DNA from cases 1-3 plus the wife of case 1. Genomic DNA was extracted from whole blood and screened for mutations in PAX2. A heterozygous PAX2 mutation (exon 2; NM_003987.3:c.76dupG, p.Val26Glyfs*28) was identified in all three cases, but not in the wife of case 1 (fig. 2). Case 1 did not have a preceding family history of renal disease, suggesting a possible de novo mutation of the PAX2 gene. In addition, careful ophthalmoscopy revealed bilateral optic nerve atrophy in cases 1 and 3, but case 2 exhibited bilateral glaucomatous cupping (fig. 3 ).

Taking PAX2 mutation into account, we performed electron microscopic examination of the first biopsy from case 1 . No electron-dense deposits were observed. Foot processes were generally well preserved, but segmental loss of podocytes was observed (fig. 4a). Many podocytes had several vacuoles and some also had large phagosomes (fig. 4b). Several swollen endothelial cells containing vacuoles were also observed (fig. 4c). About half of the mesangial cells had many vacuoles; in some of these vacuoles, degenerating mitochondria and the debris of membranous structures were apparent (fig. 4d). Phagosomes were also occasionally observed in the mesangial cells (fig. 4c, d).

\section{Discussion}

In this study, we report diverse renal phenotypes, such as FSGS and CAKUT, in a single family with PAX2 mutation. The proband did not have any family history of renal disease, suggesting a possible de novo mutation of $P A X 2$. It has been estimated that approximately $50 \%$ of PAX2 mutations occur de novo [2]. Genetic studies have shown that familial FSGS is a disease of podocytes, which are major components of the glomerular filtration barrier [4]. 


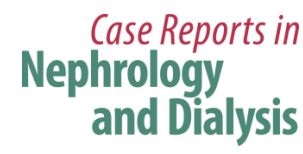

\begin{tabular}{l|l}
\hline Case Rep Nephrol Dial 2016;6:61-69 \\
\hline DOI: 10.1159/000445679 & $\begin{array}{l}\text { (c) 2016 The Author(s). Published by S. Karger AG, Basel } \\
\text { www.karger.com/cnd }\end{array}$ \\
\hline
\end{tabular}

Iwafuchi et al.: Diverse Renal Phenotypes Observed in a Single Family with a Genetic Mutation in Paired Box Protein 2

The associated mutated genes can be divided into the following categories: (a) slit diaphragm-associated molecules, (b) podocyte cytoskeleton-related molecules, (c) podocyte transcription factors, and (d) adhesion and extracellular matrix molecules [5].

The PAX2 gene, which encodes a transcription factor, is expressed in primitive cells of the kidney, ureter, eye, ear, and central nervous system. PAX2 mutations are particularly associated with RCS, which comprises renal defects and ocular defects affecting the optic nerve and/or the retina [6]. In the present family, case 1 showed steroid-resistant FSGS with optic coloboma. In other recent reports of PAX2 mutations, Barua et al. [3] reported 24 patients from seven unrelated families with FSGS, and Okumura et al. [7] reported an additional three cases of sporadic FSGS. These findings expanded the phenotypic spectrum associated with PAX2 mutations.

In case 1, almost half of the mesangial cells had unusually numerous vacuoles; in some of them, degenerating mitochondria and the debris of membranous structures were found. These electron microscopic findings suggested autophagic dysfunction in mesangial cells, although autophagy in the kidney has been attributed to podocytes and tubular cells [8]. Interestingly, in a study by Sooparb et al. [9], using cultured rat renal epithelial cells, chaperone-mediated autophagy contributed to the regulation of growth of tubular kidney cells through degradation of $P A X 2$, indicating the possibility that chaperone-mediated autophagy and $P A X 2$ could play roles in epithelial cell growth. It has been suggested that autophagic dysfunction may also contribute to pathological processes in mesangial and endothelial kidney cells [10].

It should be noted that detailed funduscopic examination - including the optic disc - is useful for the diagnosis of renal defects associated with PAX2 mutation. Although 25 years ago we could not observe optic disc coloboma using a portable ophthalmoscope, it was detectable by slit lamp microscopy, which is widely used for funduscopic examination today. As in the present cases, $P A X 2$-associated CAKUT and FSGS can be identified through a detailed eye examination including the optic disc.

In the present study, all three cases possessed a heterozygous c.76dupG variant mutation (NM_003987.3:c.76dupG, p.Val26Glyfs*28) in exon 2. Interestingly, a similar mutation has previously been reported in several patients with RCS [11-13] and is also responsible for the Pax2 ${ }^{1 \text { Neu }}$ mutant mouse, an animal model of human RCS [14]. In a study by Barua et al. [3], three of seven PAX2-associated FSGS families carried a mutation located in the paired domain near the $\mathrm{N}$-terminus of the protein. These three variants were predicted to affect PAX2 binding to DNA. In the present family, the mutation (NM_003987.3:c.76dupG, p.Val26Glyfs*28) was also located in the paired domain region, but the phenotypes were variable, with anticipation of the renal phenotype. Genotype-phenotype correlations for PAX2 mutations are not clear [15].

In conclusion, $P A X 2$ mutation can present as steroid-resistant FSGS; detailed funduscopy including the optic disc is useful for the diagnosis of renal anomalies associated with these mutations. We should be aware that PAX2 mutations can present not only as CAKUT but also as FSGS. PAX2 mutation should be listed as a differential diagnosis of FSGS. We hypothesized that autophagic dysfunction was associated with the pathophysiology of FSGS with PAX2 mutation. If FSGS associated with $P A X 2$ mutations remains unrecognized, unnecessary and ineffective immunosuppressive agents may be used for such patients. Further studies should be conducted to determine whether renal defects associated with PAX2, including FSGS and CAKUT, may be more common than previously thought. 
Iwafuchi et al.: Diverse Renal Phenotypes Observed in a Single Family with a Genetic Mutation in Paired Box Protein 2

\section{Acknowledgment}

The authors are grateful to Mr. N. Sakamoto, Ms. S. Tsuchida, Ms. M. Yoshinuma, and Ms. M. Igashima (Department of Pathology, Shinrakuen Hospital) for their technical assistance.

\section{Statement of Ethics}

The authors have no ethical conflicts to disclose.

\section{Disclosure Statement}

The authors declare that they have no conflict of interest.

\section{References}

1 Harshman LA, Brophy PD: PAX2 in human kidney malformations and disease. Pediatr Nephrol 2012;27: 1265-1275.

-2 Bower M, Salomon R, Allanson J, Antignac C, Benedicenti F, Benetti E, Binenbaum G, Jensen UB, Cochat P, DeCramer S, Dixon J, Drouin R, Falk MJ, Feret H, Gise R, Hunter A, Johnson K, Kumar R, Lavocat MP, Martin L, Morinière V, Mowat D, Murer L, Nguyen HT, Peretz-Amit G, Pierce E, Place E, Rodig N, Salerno A, Sastry S, Sato T, Sayer JA, Schaafsma GCP, Shoemaker L, Stockton DW, Tan WH, Tenconi R, Vanhille P, Vats A, Wang X, Warman B, Weleber RG, White SM, Wilson-Brackett C, Zand DJ, Eccles M, Schimmenti LA, Heidet L: Update of PAX2 mutations in renal coloboma syndrome and establishment of a locus-specific database. Hum Mutat 2012;33:457-466.

-3 Barua M, Stellacci E, Stella L, Weins A, Genovese G, Muto V, Caputo V, Toka HR, Charoonratana VT, Tartaglia M, Pollak MR: Mutations in PAX2 associate with adult-onset FSGS. J Am Soc Nephrol 2014;25:1942-1953.

-4 Laurin LP, Lu M, Mottl AK, Blyth ER, Poulton CJ, Weck KE: Podocyte-associated gene mutation screening in a heterogeneous cohort of patients with sporadic focal segmental glomerulosclerosis. Nephrol Dial Transplant 2014;29:2062-2069.

5 Chen YM, Liapis H: Focal segmental glomerulosclerosis: molecular genetics and targeted therapies. BMC Nephrol 2015;16:101.

-6 Madariaga L, Morinière V, Jeanpierre C, Bouvier R, Loget P, Martinovic J, Dechelotte P, Leporrier N, Thauvin-Robinet C, Jensen UB, Gaillard D, Mathieu M, Turlin B, Attie-Bitach T, Salomon R, Gübler MC, Antignac C, Heidet L: Severe prenatal renal anomalies associated with mutations in HNF1B or PAX2 genes. Clin J Am Soc Nephrol 2013;8:1179-1187.

7 Okumura T, Furuichi K, Higashide T, Sakurai M, Hashimoto S, Shinozaki Y, Hara A, Iwata Y, Sakai N, Sugiyama K, Kaneko S, Wada T: Association of PAX2 and other gene mutations with the clinical manifestations of renal coloboma syndrome. PLoS One 2015;10:e0142843.

-8 Takabatake Y, Kimura T, Takahashi A, Isaka Y: Autophagy and the kidney: health and disease. Nephrol Dial Transplant 2014;29:1639-1647.

-9 Sooparb S, Price SR, Shaoguang J, Franch HA: Suppression of chaperone-mediated autophagy in the rena cortex during acute diabetes mellitus. Kidney Int 2004;65:2135-2144.

10 Chévrier M, Brakch N, Céline L, Genty D, Ramdani Y, Moll S, Djavaheri-Mergny M, Brasse-Lagnel C, Annie Laquerrière AL, Barbey F, Bekri S: Autophagosome maturation is impaired in Fabry disease. Autophagy 2010;6:589-599.

-11 Amiel J, Audollent S, Joly D, Dureau P, Salomon R, Tellier AL, Augé J, Bouissou F, Antignac C, Gubler MC, Eccles MR, Munnich A, Vekemans M, Lyonnet S, Attié-Bitach T: PAX2 mutations in renal-coloboma syndrome: mutational hotspot and germline mosaicism. Eur J Hum Genet 2000;8:820-826.

-12 Sanyanusin P, McNoe LA, Sullivan MJ, Weaver RG, Eccles MR: Mutation of PAX2 in two siblings with renalcoloboma syndrome. Hum Mol Genet 1995;4:2183-2184.

-13 Schimmenti LA, Shim HH, Wirtschafter JD, Panzarino VA, Kashtan CE, Kirkpatrick SJ, Wargowski DS, France TD, Michel E, Dobyns WB: Homonucleotide expansion and contraction mutations of PAX2 and inclusion of Chiari 1 malformation as part of renal-coloboma syndrome. Hum Mutat 1999;14:369-376. 
Case Reports in

Nephrology and Dialysis

\begin{tabular}{l|l|}
\hline Case Rep Nephrol Dial 2016;6:61-69 \\
\hline DOI: 10.1159/000445679 & $\begin{array}{l}\text { ○ } 2016 \text { The Author(s). Published by S. Karger AG, Basel } \\
\text { www.karger.com/cnd }\end{array}$ \\
\hline
\end{tabular}

Iwafuchi et al.: Diverse Renal Phenotypes Observed in a Single Family with a Genetic Mutation in Paired Box Protein 2

14 Porteous S, Torban E, Cho NP, Cunliffe H, Chua L, McNoe L, Ward T, Souza C, Gus P, Giugliani R, Sato T, Yun K, Favor J, Sicotte M, Goodyer P, Eccles M: Primary renal hypoplasia in humans and mice with PAX2 mutations: evidence of increased apoptosis in fetal kidneys of Pax2(1Neu) +/- mutant mice. Hum Mol Genet 2000;9: $1-11$.

15 Adam J, Browning AC, Vaideanu D, Heidet L, Goodship JA, Sayer JA: A wide spectrum of phenotypes in a family with renal coloboma syndrome caused by a PAX2 mutation. Clin Kidney J 2013;6:410-413.
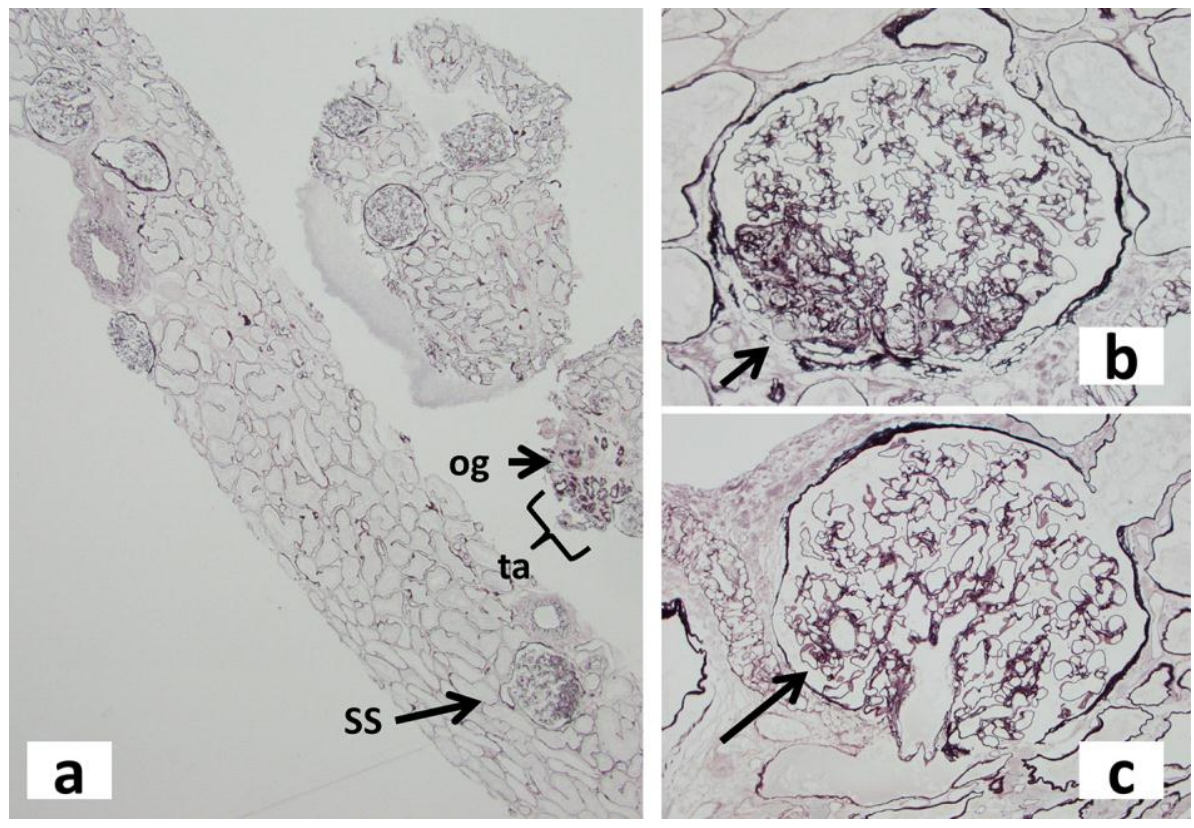

Fig. 1. a Glomeruli show essentially minor changes, but one glomerulus has segmental sclerosis (ss) and another glomerulus is obsolescent (og) in a localized area of tubular atrophy (ta). Periodic acid-silver methenamine stain, $\times 48$. $\mathbf{b}$ In this glomerulus segmental sclerosis with hyaline deposits (arrow) near the vascular pole is observed, but other portions show essentially normal appearance. Periodic acid-silver methenamine stain, original magnification $\times 400$. c This glomerulus appears almost normal, except for a segmental questionable increase in mesangial matrix (arrow). Periodic acid-silver methenamine stain, original magnification $\times 400$. 
Case Reports in

Nephrology

and Dialysis

C G G G G G G T G T T T G T G A

Case 1

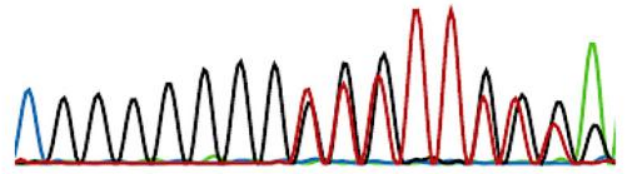

C G G G G G G T G T T T G T G A

Wife of case 1

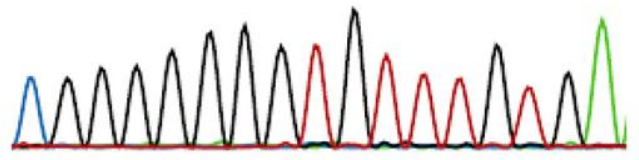

C G G G G G G G T G T T T G T G

C G G G G G G T G T T T G T G A

Case 2

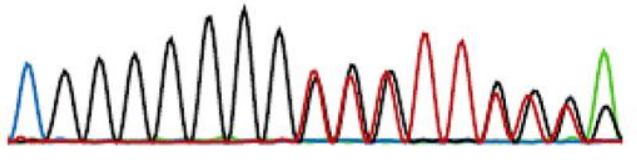

C G G G G G G G T G T T T G T G

C G G G G G G T G T T T G T G A

Case 3

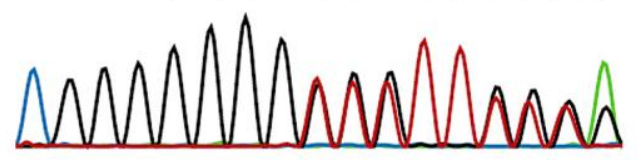

NM_003987.3:c.76dupG, V26fs*28

Fig. 2. A heterozygous PAX2 mutation (exon 2; NM_003987.3:c.76dupG, p.Val26Glyfs*28) was identified in all three cases, but not in the wife of case 1 . 
Case Reports in

Nephrology

and Dialysis
Case Rep Nephrol Dial 2016;6:61-69

\begin{tabular}{l|l}
\hline DOI: $10.1159 / 000445679$ & (C) 2016 The Author(s). Published by S. Karger AG, Basel
\end{tabular} www.karger.com/cnd

Iwafuchi et al:: Diverse Renal Phenotypes Observed in a Single Family with a Genetic Mutation in Paired Box Protein 2
Case 1

Case 2

Case 3
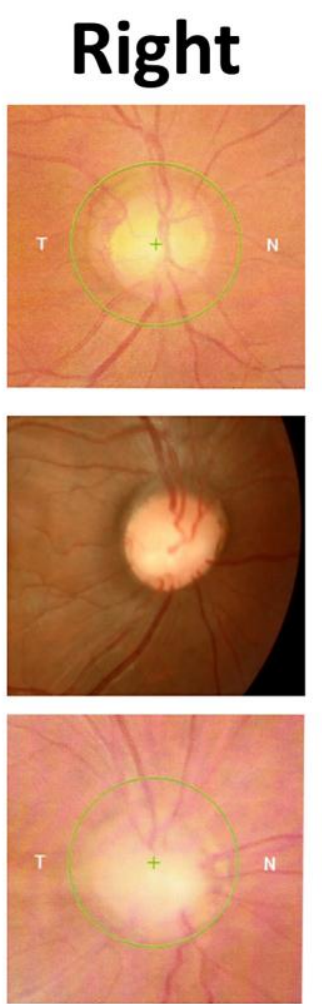

Left
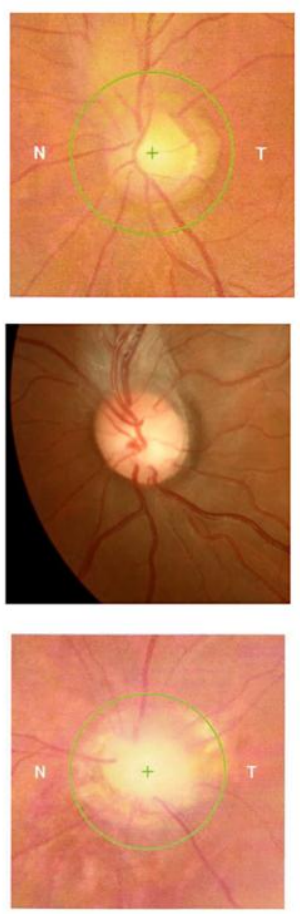

Fig. 3. Ophthalmoscopy revealed bilateral optic nerve atrophy in cases 1 and 3, but in case 2 it revealed bilateral glaucomatous cupping. 


\section{Case Reports in \\ Nephrology and Dialysis}

\begin{tabular}{l|l|}
\hline Case Rep Nephrol Dial 2016;6:61-69 \\
\hline DOI: 10.1159/000445679 & $\begin{array}{l}\text { @ 2016 The Author(s). Published by S. Karger AG, Basel } \\
\text { www.karger.com/cnd }\end{array}$ \\
\hline
\end{tabular}

Iwafuchi et al.: Diverse Renal Phenotypes Observed in a Single Family with a Genetic Mutation in Paired Box Protein 2

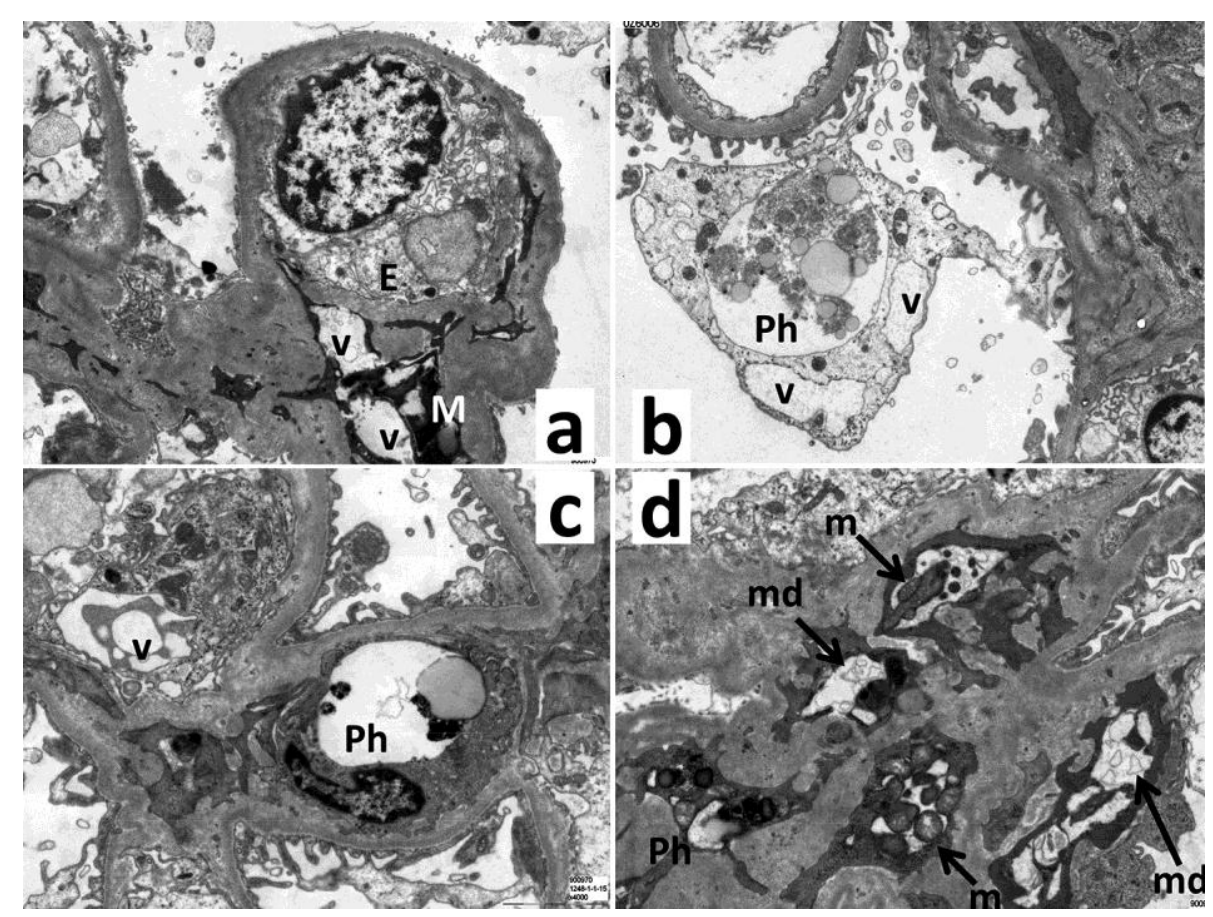

Fig. 4. a Segmental loss of podocyte, swollen endothelial cell (E), and vacuoles (v) in the mesangial cell (M) are observed. b Foot processes are well preserved; a large phagosome (Ph) and vacuoles (v) are found in the cytoplasm of the podocyte. c A large phagosome ( $\mathrm{Ph}$ ) in the mesangial cell and vacuole (v) containing swollen cell are observed. $\mathbf{d}$ Some mesangial vacuoles contain degenerating mitochondria (arrows $\mathrm{m}$ ) and membranous debris (arrows md); a lipid-containing phagosome ( $\mathrm{Ph}$ ) is also found in the mesangial cell. 